\title{
Transposition
}

Musique et Sciences Sociales

Hors-série 2 | 2020

Sound, Music and Violence

\section{Did Music Cause the End of the World?}

La musique a-t-elle causé la fin du monde?

\section{J. Martin Daughtry}

\section{(2) OpenEdition}

\section{Journals}

Electronic version

URL: http://journals.openedition.org/transposition/5192

DOI: 10.4000/transposition.5192

ISSN: $2110-6134$

\section{Publisher}

CRAL - Centre de recherche sur les arts et le langage

\section{Electronic reference}

J. Martin Daughtry, « Did Music Cause the End of the World? », Transposition [Online], Hors-série 2 | 2020, Online since 15 March 2020, connection on 16 April 2020. URL : http://journals.openedition.org/ transposition/5192 ; DOI : https://doi.org/10.4000/transposition.5192

This text was automatically generated on 16 April 2020

\section{(c) (†) ()}

La revue Transposition est mise à disposition selon les termes de la Licence Creative Commons Attribution - Partage dans les Mêmes Conditions 4.0 International. 


\section{Did Music Cause the End of the World?}

La musique a-t-elle causé la fin du monde?

J. Martin Daughtry

\section{AUTHOR'S NOTE}

A formidable group of people provided me with valuable thoughts and critiques of this essay. They include Mike Beckerman, Harris Berger, Zeynep Bulut, Samuel Chan, Beverley Diamond, Nina Eidsheim, Brian Fairley, Meghan Forsyth, Annie Garlid, Jairo Moreno, Daniel Oore, Anna Papaeti, Robin Preiss, Joel Rust, David Samuels, Joe Snape, Kati Szego, Hila Tamir, Tyler Volk, the Spring 2020 Applied Ethnomusicology seminar participants at Memorial University, and my family. Luis Velasco-Pufleau solicited and edited the essay; I am grateful to him, to the other contributors to this issue, and to the editorial team at Transposition for their support throughout the writing and publication process. Special acknowledgment goes to the musical voices that populate this essay: first and foremost, Yōsuke Yamashita, but also Kiyoshi Awazu, Cole Porter, Ella Fitzgerald, and the many music practitioners and communities mentioned within these pages. The footnotes and list of works cited form a partial acknowledgment of the many scholars I'm grateful to be in conversation with. Given the expansive scope of the essay's theme, it also seems appropriate to acknowledge my debts to the mindbogglingly diverse collection of creatures, plants, habitats, machines, and other enigmatic entities that exist within the most anthropocentric and essentializing of all terms: "nonhuman."

\footnotetext{
"We need to understand the body, not as an organism or entity in itself, but as a system, or series of open-ended systems, functioning within other huge systems it cannot control through which it can access and acquire its abilities and
} 


\section{capacities." \\ -Elizabeth Grosz \\ "There is no document of civilization which is not at the same time a document of barbarism." \\ -Walter Benjamin \\ "Every time we say goodbye / I die a little."}

-Cole Porter

\section{Transcorporeality}

1 The body called "piano" stood on top of the body called "beach," separated from the ragged fringe of the oceanic body by several meters. ${ }^{1}$ The invisible body called "air" blanketed piano, beach and ocean, subtly pushing its way into each of them, blurring lines of separation. An array of bodies collectively called "audience" stood nearby, clapping hands together as a single body called "avant-garde jazz pianist Yōsuke Yamashita" pushed through air, atop beach, in a path toward piano. Yamashita was acting according to instructions that a body called "graphic designer Kiyoshi Awazu" had first composed for a performance in 1973. Thirty-five years later, as the Awazu body was nearing its final return to the body called "earth" through a process called "decomposition," Yamashita was repeating the old instructions. Much was the same, although the piano body from the original performance had long ago burned up, rejoining the embrace of earth and air.

2 The body called Yamashita-which, like "audience," "beach," "ocean," "air," and "piano," was really a swirling, gurgling concatenation of smaller bodies-was clad in a metallic fire-retardant coat and helmet. (The metal in these clothes-bodies had been extracted from a body called "mountain" and refined in a body called "smelting plant" some years before being painted on fibers formerly called "sheep.") Sitting down on a low-slung body called "bench," Yamashita began impacting piano, causing thin metal bodies called "strings" in its interior to vibrate and in so doing perturb air. These vibrations quickly reached the audience bodies, and altered chemical and electric flows within each of them, differently. They also reached a collection of feathered bodies called "birds," who flew away in response.

3 After a time, as the fingers continued to elicit the vibrations, a parallel process called "fire" was initiated through a hidden mechanism that created a spark in piano. Fire began transforming piano (which had formerly gone by the names "tree," "mountain," "sheep," and possibly "elephant") into a distributed, cloudlike body called "smoke" that moved in a rolling, roiling motion within the vast substance of air. Fire flickered and swooped and crackled and changed color and pulsated and grew, with smoke and an invisible body called "heat" fleeing from it. Fire transformed strings, causing them to stretch and soften and break, one by one. The fingers protruding from the metallic coat continued to pound away at piano, although the vibrations they elicited grew weaker and weaker, and were soon overtaken by the crackling vibrations fire made.

4 The body called smoke continued to billow off piano, growing far larger and reaching far further into air than the vibrations ever could. Smoke now roamed in air over beach and a growing piece of ocean. Air was active in several registers by this point; radiating and convecting heat, it sent vibrations to audience, oxygen to fire, and a barely viable mixture of oxygen, nitrogen, argon, carbon dioxide, and smoky piano body to the lungs of Yamashita and a downwind subsection of audience. Buffeted by smoke (formerly "piano," more formerly "mountain," "tree," "sheep," etc.) and heat and flames from the ever-encroaching fire, the fingers pounded and pounded against 
the shrinking, increasingly compromised piano, with less and less vibrational effect. After a while, piano could no longer be called "piano," as it had lost nearly all of its piano-like characteristics. Having briefly become "detuned," then "broken," then "toy" piano, it was now best called "fuel" for fire. This identity loss and reclassification, along with the toxic grey cloud of hot smoke into which the former piano was being transformed, evidently proved too much for Yamashita: carrying an indeterminate amount of aspirated former piano inside the sticky labyrinths of his lungs, the human performer retreated through air along beach, as ocean waves lapped and audience hands once again clapped. In his absence, fire, fuel, smoke, and air continued their monstrous, entropic dance.

This 2008 performance, which was called "Burning Piano," seemed to have a clear initiation point (i.e., the moment of first contact between piano and Yamashita) but no clear ending: the tiny atomic bodies that made up smoke and ash continued to invade air and lung and earth indefinitely-indeed, they are still doing so now, floating along on invisible atmospheric currents, descending to earth or ocean, loosing their chemical bonds, forming new ones, cycling back up into air, and so on, ad infinitum. Such is the nature of atmosphere and the carbon cycle that a few atoms of the body called piano could literally be present in the room or outdoor space where you are reading this: piano, that piano, could be cycling through your lungs at this very moment. This fact can be stretched into an aphorism: while all performances begin, no performances truly end; rather, they all taper off, in an asymptotic decrescendo of sorts, as the various bodies that they manipulate and transform and unleash eternally continue to make pathways through-and exert effects within-the aggregate body called "environment" (a.k.a. "biosphere," a.k.a. "world"). ${ }^{2}$ This means that the palimpsest of ongoing earthly performances is gaining new layers at an ever-accelerating rate. "Burning Piano" intensifies and spectacularizes these more-than-human trajectories; my self-conscious attempt to track them without privileging the human or sonorous aspects of the performance is designed to highlight them further. Here, the burning instrument and hot smoky air reveal themselves as active entitiesentities that simultaneously sustain, shape, threaten, and ultimately overwhelm the humans with which they are irreversibly involved. No clean line separates any of these human and nonhuman bodies from the others. They are trans-corporeal, ${ }^{3}$ intra-active, ${ }^{4}$ and co-vulnerable. However, these prefixes (trans-, intra-, co-), illuminating as they are, fail to convey the asymmetry and temporal dynamism of any body's environmental entanglements. To wit: the different bodies (piano, performer, audience, air, etc.) were agentive and vulnerable and accountable to one another in different ways, with different stakes, at different moments. Yamashita (or, more likely, his technical assistant) may have lit the fire, but after that, air-firepiano took control, dictating the volume and timbre and length of his participation, not to mention the actuarial cost of his smoke inhalation on that fateful day. Smoke, a necessary byproduct of the performance, darkened the sky above the audience and contributed fractally to atmospheric processes whose consequences involve but vastly exceed the acoustical, aesthetic, social, and political realms we tend to associate with music. Music, however you choose to define or problematize this bedeviling term, is the product of dynamically and asymmetrically covulnerable bodies, only some of which are human.

\section{Registers}

6 In what ways can music become entangled with violence? The essays in this special issue of Transposition provide a number of compelling answers to this question, extending considerably the work of music scholars over the past few decades. ${ }^{5}$ In this 
essay, I want to begin by suggesting that any attempt to understand the relationship between music and violence must necessarily approach this subject from within a certain frame of reference or register-a default orientation that carries a particular epistemology and set of spatiotemporal parameters along with it. ${ }^{6}$ I need to assert at the outset that registers are not neutral things; like funhouse mirrors, they inevitably distort that which they reflect. Despite decades of critical scholarship on this topic, academic authors tend to ignore the distortive properties of the registers they activate, representing them as more-or-less transparent framing devices: faithful magnifying lenses rather than the slightly surreal soap-bubble projections they are. ${ }^{7}$ We ignore the inconvenient fact that the application of a particular register to a problem creates its own ripple of symbolic violence: every act of framing requires a series of exclusions, reductions, and Procrustean cuts that leave some parties marginalized and others out of the conversation altogether. Reality is infinitely polyscalar-like a Russian nesting doll, you and I envelop and are enveloped by bodies and processes taking place at multiple orders of magnitude simultaneously. ${ }^{8}$ Nonetheless, whether we acknowledge them or not, registers are unavoidable: there is no registerless position from which to observe the infinite complexity of the world, nor is there an all-inclusive framing device that embraces all entities equally while retaining the radical individuality of each of them. In this funhouse environment, the best one can do is maintain an awareness of the registers that one has activated, and develop a feel for both the distortions and the insights they produce. (I am belaboring this point here at the beginning because the register I will deploy later in this essay creates an almost comical level of distortion; my hope is that the strange vantage point it affords will make the essay worth the read.)

7 Scholars and music listeners often place music in a phenomenological register, examining it within the temporal and spatial conditions of its unfolding in performance. To think of music phenomenologically is to foreground its acoustical, echoic properties, as well as the embodied act of listening, the transmission of affect, and the micro-social intensities that musical performances tend to engender. A music theoretical register, by contrast, tends to place a particular musical work in a kind of contemplative, conditional freeze-frame: a non-space/non-time that allows it to be apprehended outside of its unfolding, as if it is in stasis, present all at once like a painting; this allows one to leisurely examine its different constituent parts, their behaviors and interactions, and the ways these parts articulate with other structures external to the piece. Music is also frequently placed within a historical register, which allows broader diachronic phenomena to be sensed; at this scale one can grasp the trajectory of a composer's oeuvre, or a genre's lifespan, or the pathways a song traces within globalized networks of consumption. A cultural or ethnographic register brings people into focus, along with the webs of significance that they inherit and continually shape. ${ }^{9}$ It may not surprise you to learn that scholars tend to place violence-another human construct, with a historical depth and global reach that rival those of music-within a phenomenological register of embodied experience and traumatic memory, a theoretical register of quantitative or comparative analysis, a historical register that links major conflicts with their precursors and their aftermaths, and a cultural register that seeks to situate discrete acts within local systems of meaning. While registers such as these can be combined in fruitful and exciting ways, it stands to reason that when one seeks to understand how two distinct phenomena interact, it is desirable to 
harmonize or synchronize the temporalities and spatialities at which they are apprehended.

\section{Slowness}

And herein lies a challenge, for what can one possibly say about music in the dyad "music and violence" if the violence one has in mind is not the "hot violence" of retribution or impassioned aggression, nor the "cold violence" of premeditated individual or state killing, nor even the "symbolic violence" that Pierre Bourdieu found within structures of social inequity, ${ }^{10}$ but rather what environmental humanities scholar Rob Nixon has called the "slow violence" of large-scale practices of pollution and extraction that have destabilized the earth's biosphere?"11 "Slow violence," Nixon explains, is "a violence that occurs gradually and out of sight, a violence of delayed destruction that is dispersed across time and space, an attritional violence that is typically not viewed as violence at all." 12 While caused by human activities, slow violence is inhuman in the sense that it often operates at spatial, temporal, and conceptual scales too vast or foreign for humans to perceive, let alone control. The current state of escalating precarity throughout the biosphere is to a great extent the result of the slow violence of industrial processes (from carbon combustion to factory farming to nuclear testing) that had beginnings, but because of their durational effects and long half-lives, never properly end. What we see or hear or smell or feel today, in a forest fire, or a record breaking heatwave, or a sinking island, or a methane spike, or a toxic algae bloom, or a cancer outbreak, are the effects of slow violence rather than the processes themselves, which are ongoing and imperceptible. ${ }^{13}$

9 Nixon argues that these processes disproportionately affect "people lacking resources," and he tracks the colonial pathways that have allowed the world's wealthy classes to direct the brunt of slow violence toward the global poor. (Colonialism, in his analysis, is the slow-violence-generator par excellence.) At the same time he acknowledges that, while wealthy populations may be better insulated against environmental calamity than poor populations, the interconnectedness of our ecologies and economies means that there are (largely future) effects of slow violence that will be shared throughout the biosphere. The global scale of carbon emissions, along with the atmospheric warming, habitat destruction, and species extinctions that it has begun to trigger and/ or exacerbate, threatens the entire planetary system; this kind of violence doesn't draw a clean line between human groups, or even between human and nonhuman bodies.

10 Some manifestations of slow violence were initiated relatively recently (e.g., through 20th-century nuclear testing in the Marshall Islands, or 21st-century exportation of ewaste to China); others have been gradually accelerating over the course of the industrial age (e.g., ocean acidification through the absorption of atmospheric carbon); or even since the dawn of agriculture 12,000 years ago (e.g., increased greenhouse gases from deforestation and early farming). What is clear is that some of the humans who preceded us set in motion slow, snowballing processes whose effects large populations of humans and nonhumans must now endure; it is equally clear that those of us whose lives are tied to carbon emissions and factory farms and microplastics and laptop heavy metals are participants in a multi-species slow violence whose victims stretch deep into the future. 
11 With all this in mind, we can now state the question at hand more precisely: in what ways have music and slow environmental violence become entangled? There are two potential vectors of causation embedded in this question: one pointing to the ways that environmental violence has impacted music praxes over time, and another addressing the ways in which musicking might have caused or exacerbated environmental violence. The first vector is familiar: it is the subject of a wealth of music scholarship dealing with recent environmental crises from Fukushima to Katrina to climate migration in Europe. ${ }^{14}$ (Indeed, it is becoming impossible to do anthropological work on music or any other topic without taking environmental issues such as these into account.) The second is more counterintuitive, particularly if one takes the slow pace and global scope of slow violence into account. If we were to phrase this counterintuitive question more precisely, it would sound like this: what has been the net environmental effect of music over the course of the age of humans? Another formulation, with a nod to Nixon, would be: does music have an "attritional" effect on environment? In what follows, I will take on these questions, teasing out some of the deep structures of music (or more properly musicking, the complex of activities that brings "music" into being) that may have smoothed the path, gradually and over millennia, toward our current age of mass extinction and environmental calamity.

12 Needless to say, this is not a familiar register for most music scholars. While the fields of music cognition and psychoacoustics support research on how humans evolved musical capacities, how music and language influenced one another over time, and related questions connected largely to the evolution of the nervous and auditory systems, they tend to be confined, like most music research, to the activities of human brains, human ears, human collectives. The burgeoning field of ecomusicology provides the most logical escape route from the human-sized registers, although I am unaware of studies that attempt to answer the particular question posed above. This is no surprise, as the question itself verges on the nonsensical: how could music-not just one type of music, but the totality of music throughout history-be in any way complicit with environmental violence-not just one instantiation of it, but the totality of anthropogenic pollution and climate change?

\section{Apocalypse}

Indeed, it would be easy to argue that music and the environmental register are fundamentally incompatible. A frame this expansive cannot capture discrete phenomena like individual musical experiences, individual musicians' lives, individual genres' lifespans, or even the social histories of music over a span of centuries. The scintillating diversity of the world's musical praxes-the profound textual and contextual distinctions that separate a German symphony from a Brazilian work song from a Norwegian heavy metal album from a Balinese gamelan performance-are impossible to discern at this all-inclusive scale. Compositional genius, performative virtuosity, cultural idiosyncrasy, alternative epistemologies and aesthetics-so many of the attributes that give music praxes their distinctive grain are sanded down into the sublime smoothness of the environmental register's stretched-out timeline and planetary embrace. This spatiotemporal vastness only increases the distortion that is present in all registers; the fact that you and I, as humans, cannot directly perceive environmental space or time, but rather can only imagine or speculate about it, 
multiplies these distortions further. Under these circumstances, one might be tempted to withdraw the question altogether, eschew the speculative register it relied upon, and allow the sciences to tell the story of pollution and climate change in graphs and figures. But a retreat to data and empiricism hardly corrects the problem of interpretive distortions, and utterly fails to get at the urgent ethical, political, and aesthetic questions that are tied up in music's relation to environment. In the end, speculation may be the only way to even begin to address them.

So what does this speculative environmental register capture? Let me preview a bit of my conclusion here, and suggest that it captures a metaphysics. The metaphysics I have in mind is not the only one that music praxes have underwritten over the course of human history-far from it-but it is the one that has come to dominate global life, the one that has had the greatest environmental effects, and the one that thus far has proven impossible to dispel, even in the face of ongoing and intensifying ecological catastrophe. It provides the ground for a widespread understanding of the concepts "human" and "nature" as separate and unequal, agent and background.

Much of the public discourse on environmental violence is oriented toward the "the end of the world as we know it," a cataclysmic event horizon that looms sometime in the indeterminate future, a number of decades or at most centuries from now. It is common to cite the rising level of carbon dioxide and other greenhouse gases in the atmosphere, and to project that, if levels aren't reduced or zeroed out within X amount of time, positive feedback loops will be established that will make global warming irreversible-and, some time later, human life as we know it impossible. If we are to avoid this fate, the argument goes, a number of globally coordinated actions and technological solutions will need to be undertaken within a particular temporal window. A growing number of authors have begun to counter this "apocalyptic" discourse with a "post-apocalyptic" one, arguing that "the end of the world has already occurred." This is not as unreasonable a statement as it might sound: "Clearly, planet Earth has not exploded," writes ecological theorist Timothy Morton, "[b]ut the concept world"-i.e., an all-encompassing, stable, generative environment for biological and cultural life-"is no longer operational." ${ }^{15}$ Philosopher Claire Colebrook adds an important element of social critique to this argument when she says that the future "end of the world" that haunts climate change discourse actually involves "the sorts of conditions that most humans have been living in, and are still living in" ${ }^{16}$ To say that the world has already ended is in this sense not an apocalyptic anachronism, but an acknowledgment of the ongoing fragility of our fellow humans and other creatures, and thus of the artificiality and exclusivity of the concept "world" itself. And so, nonsensical as it sounds at first hearing, a final formulation of the question at hand is this: did musicking play a role in bringing about the end of the world?

\section{Humanity}

16 I'll return to this question presently, but first I want to introduce some broad observations about the nature of music that a number of my colleagues have made in recent years. Collectively, they help us to see the contours of what one might call the "civilizational register," one that measures time in millennia but keeps the focus tightly on human modes of being. Elizabeth Tolbert, one of the rare ethnomusicologists who has explored musicking within an evolutionary frame, has suggested that humans 
value music in part for the sensation of co-presence and authentic connection with other humans that it affords: "[W]e understand music in the most general sense as a vehicle for cultural truth," she writes, "because we hear music as the socially meaningful presence of another person." She continues:

We understand music as an embodied voice, produced directly from a human throat or by instrumental proxy, yet retaining its identity as a "humanly organized sound" (Blacking, 1973: 26). Even though we may perceive musical form, when hearing a musical voice we cannot help but hear more than pure structure. We grasp a social essence, one that is emotionally and corporeally informed. On some level, we glimpse the body behind the voice, a body whose voice refers to the imagined socio-emotional essence of its figurative producer (Barthes, 1977). This voice is not merely an object, but a voice of an intentional being such as oneself, and one that therefore references states of arousal, attention, and emotion. Thus, an encounter with the voice is, above all, an intercorporeal encounter with a social presence, and we bring to it our social, corporeal, and enacting selves. ${ }^{17}$

For Tolbert, musicking facilitates an experience of connection with other humans. Music is saturated by the energy of the human body, even when the performing body is absent. Tolbert isn't arguing that music provides listeners and performers with actual, unmediated access to one another's inner lives. What it can do is project a sensation of unmediated copresence: the "intercorporeal encounter" that music facilitates is in this sense a virtual one-but it is no less powerful for that.

In a complementary vein, musicologist Morag Grant (in this very issue of Transposition) emphasizes the communitarian power that musicking holds. She writes:

Musical practices are very often collective practices, and thus specific forms of collective experience: in the act of singing, playing or listening to and moving with music in the company of others, but also, at a distance, through the sense of sung or felt rather than purely imagined communities that particular pieces of music engender where they have become symbolically connected to, and expressive of, particular collective identities. In both these cases, but particularly in the former, to collectively experience music is to enact collectivity itself, and simultaneously to have collectivity enacted upon one, thanks to the processes known as entrainment which are arguably one of the most significant and fundamental aspects of music and musicality per se. Whether actively keeping together in time, or simply being together in time through the uniting force of a common music--such as an anthem, or other type of group song--the potential of musicality and musical communication for collective identity cannot be overstated, though it is often overlooked. ${ }^{18}$

Grant's observations about music's efficacy are framed within a sociocultural register: the scale of "real" (i.e., face-to-face) and "imagined" (e.g., national) collectives that share a particular musical experience or genre. These thoughts can be extended into the civilizational register without too much distortion, however, given that the most fundamental of the "particular collective identities" that music is "symbolically connected to, and expressive of" is, arguably, that of the human species. This is not to deny the existence of a multitude of musical traditions that have portrayed humannonhuman relations in terms of continuity rather than disjuncture-nor is it to claim that discrete acts of musicking necessarily and consciously connect participants to some kind of universal plane of general humanity. Here, as in Tolbert's essay, the identity-crafting capacity of music is subtle; it consists of an unconscious or quasiconscious recognition, flowing slowly beneath the more powerful currents of communication and entrainment and pleasure, that these sounds were made by and for creatures like me. 

tracks the slow evolution of the human attributes that allowed musicking to come into being. One of his central claims is that " $[t]$ he set of capacities that enables musicking is a principal marker of modern humanity." Casting his gaze back to the dawn of practices that we might credibly call human musicking 200,000 years ago, he claims that "[m]usicking was always social."

If the cognitive capacities basic to it emerged from a constant, intimate interplay with available materials, their affordances, and their manipulation, all these took place, through the whole of the history here described, in the context of copresent interactions between individuals and within groups. The technological and the social were always bound together, and this technosociality formed the matrix in which musicking took shape. ${ }^{19}$

21 Elsewhere in the monograph, Tomlinson explains how musicking became entwined with the distinctly human skill of "thinking-at-a-distance." Musicking "developed alongside a 'release from proximity' whereby humans gradually gained the capacity to imagine things not present to the senses." These and other related developments led to music's emergence as "a transcendent cultural force":

In a cognition increasingly able to think at a distance, musicking pushed toward hierarchic levels beyond sensual stimuli. The bond of music and metaphysics reaches back to the first inklings themselves of other worlds. . . The final coalescing of musicking was not an independent development but a coformation involving language and the metaphysical imaginary. All three are characteristic, even definitive gestures of human modernity, and none of them could have taken their modern forms without the simultaneous formation of the others. ${ }^{20}$

Musicking, in other words, is not the singular "silver bullet" that separated us from the rest of the animal kingdom-but it is, in Tomlinson's treatment, deeply imbricated with an array of evolved capacities (e.g., thinking-at-a-distance, cultural accumulation, an incipient theory of mind) that combined to make human behavior and its collective power distinctive in the history of the biosphere.

Together, Tolbert, Grant, and Tomlinson advance complementary arguments about music's transcultural and transhistorical efficacy. Music praxes connect human participants with their "social essence[s]" and "collective identities," "push[ing]" them "toward hierarchic levels beyond sensual stimuli." Musicking brings people together in a synchronous activity that renders rich webs of human relationships-with present coperformers and imagined communities alike-audible, palpable, durable. The intense and lasting social force of musicking helps explain its ubiquity throughout the age of humans. What remains to be discussed, however, are the ways the social energies released by music may have helped shape some human attitudes toward environment, and the actions those attitudes enabled over time.

\section{Humilibris}

It bears repeating: there is, ultimately, no monolithic "human subject" or uniform global "we," no singular capacity or urge or belief system that unites all people, no inclusive habitat or politics or set of resources or rights to which all have equal access, no global industrial enterprise for which all are equally responsible. ${ }^{21}$ At the same time, it is incontestable that some human belief systems have been more widespread and influential than others. The magnitude of this spread and influence can only be 
understood in the context of the human population explosion that began in earnest after the Industrial Revolution. Consider the dynamics of this accelerating growth curve: it took roughly 11,800 years (from 10,000 BCE to $1804 \mathrm{CE}$ ) for the global population to grow from four million to one billion; by contrast, over a scant two centuries (from 1804 to 1999), humankind grew from one billion to six billion. A seventh billion was added to the world population just eleven years later. More than half of the 7.8 billion people currently on the planet are living in urban environments, and an absolute majority of all people have some exposure to the vast global archive of recorded music-an archive that presents music as yet another inexhaustible resource. An environmental register must thus encompass the long timeline of human development, the extraordinary explosion of human growth over the past two hundred years, the emergence of recording as a producer of radical musical plenitude-and the ever-increasing number of toxic emissions, habitat destructions, and species extinctions that have accompanied this planetary crescendo of all things human.

Over this span of growth and industrialization, no belief system has been more influential or widespread than the one that places humans outside and above all that they are not, that conceives of humans as special, and "nature" as separate from them. This metaphysics has been variously labeled anthropocentrism or human exceptionalism or human/nature dualism. Val Plumwood, the pioneering feminist philosopher and environmentalist, considered it to be the quintessential problem of our time:

I see human/nature dualism as a failing of my culture, time and history. Human/ nature dualism is a Western-based cultural formation going back thousands of years that sees the essentially human as part of a radically separate order of reason, mind, or consciousness, set apart from the lower order that comprises the body, the animal and the pre-human. Inferior orders of humanity, such as women, slaves and ethnic Others (so-called 'barbarians'), partake of this lower sphere to a greater degree, through their supposedly lesser participation in reason and greater participation in lower 'animal' elements such as embodiment and emotionality. Human/nature dualism conceives the human as not only superior to but as different in kind from the non-human, which as a lower sphere exists as a mere resource for the higher human one. This ideology has been functional for Western culture in enabling it to exploit nature with less constraint, but it also creates dangerous illusions by denying embeddedness in and dependency on nature." ${ }^{22}$

Human/nature dualism has undergirded virtually every form of mass thought and governmentality that has entertained global aspirations (e.g., Christianity, Islam, empire, settler colonialism, enlightenment modernity, capitalism, the industrial revolution, Leninism, Maoism, etc.). Our current era of neoliberalism or late capitalism could not have emerged without it. Its transparent logic has dominated over that of its competitors (e.g., various locally-inflected forms of perspectivism, panpsychism, hylozoism), and has provided justification for the large-scale practices of resource extraction, greenhouse gas emission, monocultural food production, environmental toxification, and human and nonhuman immiseration that accompany modern life. The logic rests on two paradoxical claims, each with its own paradoxical corollary:

-Claim \#1: humankind, as the superior species, is master of the earth and all life on it. The world is a resource for humans to utilize, exploit, and develop.

Corollary: some classes of people are more fully human than others.

-Claim \#2: we humans are so small and insignificant, and the earth is so inexhaustibly big, that nothing we could possibly do would ever impact it in a lasting way. The world is superior to us, and impervious to our actions.

Corollary: if I make an effect invisible to myself, it ceases to exist. 
The first claim, a straightforward manifestation of hubris, is clearly ill-founded; the second, a somewhat disingenuous form of humility, is demonstrably false. Fused together, they form a single compound affect, an embodied orientation to the world that removes all obstacles to slow violence. According to this orientation, while I may have ethical obligations to other humans (or at least to the ones I define as fully human), it is my absolute right to treat the non- or less-than-human world as I please, as my thriving is more important than its thriving. In any event, any action I take will be inconsequential to the environment in the long run, because my thriving is unrelated to its thriving.

This is the durable metaphysical foundation that stands behind every gallon of gas I put in my car and every sack of garbage I send off to the landfill. It undergirds the industrial revolution, nuclear testing, leisure travel, and contemporary climate change denial. Its existence in the 21st century, in the face of overwhelming evidence of its falsity, is testament to its tenacity. As such, it deserves its own term. I propose that we assign this caustic fusion of hubris and humility the straightforward portmanteau humilibris, and that we recognize it as one of the primary drivers of our current era of environmental pollution and climate instability. Refining my original question further, I want to ask whether music has played any role in the perpetuation of human/nature dualism, the humilibristic energies it produces, and the snowballing performances of slow violence-performances with beginnings but no ends-that are its legacy.

\section{Entanglement}

Before taking on this question directly, allow me to introduce one last perspective. Ethnomusicologist Ana María Ochoa Gautier has written that much of the recent scholarship on music and environment, particularly that which takes place under the rubric of ecomusicology, ends up strangely reifying human/nature dualism. ${ }^{23}$ Having established "humankind" and "nature" as separate entities, this work then installs music as the bridge between the two, presenting "music, sound, and listening . . a as that which politically resolves the separation between nature and the human or the conflictive relations between humans, understood as part of the ecological crisis. This corresponds to a conceptualization of music as that which produces community and of listening as the much-needed suture for the torn relations both between humans and between humans and the environment." ${ }^{24}$ As a result, Ochoa Gautier argues, "the political properties attributed to music, sound, and listening in its engagement with ecology are all, by default, taken for granted as a self-evident positivity." ${ }^{25}$ She concludes by echoing anthropologist Eduardo Viveiros de Castro's call for a "multinaturalism" (itself inspired by Amerindian cosmologies) that acknowledges a multiplicity of imbricated human and nonhuman modes of being. Ochoa Gautier's proposed "acoustic multinaturalism" brings sound into the discussion of the entanglement and occasional incompatibility of humans and nonhumans, and the politics of what feminist theorist Karen Barad would call their "intra-actions."

Those of us who write on music and violence have long ago left behind all notions of music as "a self-evident positivity." If the question of music's efficacy is posed from within the scale of human collectives, it is clear that music harbors many potentialities, and can be weaponized as easily as it can be used for reconciliation. If posed from the more-than-human environmental register, however, the picture changes. In what 
follows, I will argue that the cumulative effect of musicking on environment has been to subtly perpetuate an anthropocentric, humilibristic orientation to the world. In this sense and from this vantage point, one might even advance the provocative claim that music has been a self-evident negativity, a force that helped to create the conditions within which acts of slow violence could thrive and multiply.

31 At first glance, it might seem that, if music is involved in the perpetuation of anthropocentric attitudes, then all human cultural products must be equally so. Don't a bridge, and a computer, and a sculpture, and a novel, and a church, and an ICBM all provide equal fodder for the argument that humans are cognitively superior to, and ontologically separate from, other species, and from our environment more generally? Perhaps. But in what follows I will argue that several of music's affordances have rendered it particularly powerful as a technology for obscuring environmental entanglements and fueling humilibristic impulses.

This argument requires the following caveats:

Caveat 1: In what follows, I'm going to largely bracket out the rich spectrum of musical traditions whose metaphysics explicitly contradict the logics of human/nature dualism. This decision would appear to be an affront to the core sensibilities of contemporary ethnomusicology, ecomusicology, and related humanities disciplines, whose missions centrally involve creating space and respect for historically marginalized voices. Here it is necessary, however, as those traditions, while producing profound effects within local sociocultural and spiritual registers, have thus far been unable to dethrone the global hegemony of the anthropocentric worldview. (This, again, is the primary distortion of the massive register that I'm calling environmental: it fails to recognize minoritarian traditions, or human diversity more broadly.) At the end of the day, anthropocentrism is the phenomenon I'm interested in, and I want to know if the net effect of musicking, tout court, might have been to help it attain and maintain its dominant status. Thus, unless noted otherwise, the "we" to which I occasionally refer below is not an inclusive "we" of all humanity but one that points to everyone who was or is caught up in the dualistic trap: those of us who understand ourselves as an exceptional species of autonomous individuals who stand out against the backdrop of the natural world. As Plumwood has asserted, the anthropocentric attitude has a history in the West that goes back thousands of years; it has certainly become the default metaphysics of the global modernity with which "we" (radically inclusive) must all contend.

This is not to imply that the musical potentialities I describe below are wholly absent in indigenous or non-Western music traditions. To fail to acknowledge the possibility of anthropocentric agencies outside the industrial West would be to succumb to a crude form of essentialism, and to deny the existence of "alternative modernities" around the world. ${ }^{26}$ My suspicion is that many if not most people draw upon more than one worldview to make sense of their lives, and that the ability to resolve seemingly contradictory ontologies within one's experience is a core part of being human. In any case, if you're reading this essay, the chances are that you are at least partially embedded in the same humilibristic, global metaphysics that I am. You and I live, at least partially, in what sociologist Max Weber famously called the "disenchanted" world of empirical knowledge and secular institutions. (NB: the journal you are reading at this moment is one of these institutions.) This would mean, minimally, that the "music" that I reference below is "our" music: yours and mine. 
2: Within the vast musical terrain that remains, I'm also going to almost entirely ignore the dimension of words in the form of sung lyrics. The observations I will be making pertain to aspects of musicking that operate beneath and independent of the explicit theme or linguistic content any particular instantiation of musicking might have. Of course, one could argue that the presence of words in songs necessarily causes them to bend in an anthropocentric direction, no matter what those words denote. ${ }^{27}$ For isn't singing doubly indexical of humanity-the voice pointing toward the human body that produces it; the words pointing toward the minds and social histories from which they emerged? In this sense, to rely upon the presence of singing in music would be to make my task too easy. I want to try to show how a number of music's attributes may have subtly naturalized the human/nature divide, and suggest that they have the potential to do this whether or not words are present.

observations track to a certain extent with those of Tolbert, Grant, and Tomlinson, with one important difference. Within the civilizational register these authors occupy, the anthropocentric dimensions of musicking are implicitly understood to be lifeaffirming, or at the very least neutral: musicking is one of the suite of capacities that makes humans who they are. It is only within the counterintuitive territory of the environmental register that these same attributes can be understood as potentially sinister and destabilizing. And so, which of music's many attributes may have rendered it a particularly powerful agent of human/nature dualism and humilibristic thinking? Consider the following four proposals as soap-bubble distortions of musicking's longue durée history, glimpsed from the inhuman register in which slow violence takes place. While easy to puncture, they nonetheless serve as occasions to think anew about the vulnerable world they invert and reflect.

\section{Exclusivity}

Music can be broadly understood to consist of human-made sounds, unfolding in human-scaled time, tracing human-sized dramatic arcs, transmitting recognizably human affects and argumentations. From the intimate whisper of a lullaby to the rafter-rattling thrum of a metal band, music affords listeners and performers deep access to the dynamics of human bodies, human psyches, human technologies, and human collectives. What musical representations of the nonhuman exist-mimetic passages, bucolic genres, pastorales-are necessarily stylized, and hence disciplined into human aesthetic and cognitive regimes. As a result, the biosphere, if it is ever thematically present in musical sound, is necessarily shrunk down to a human scale with humans at its operative center. Regardless of its explicit themes or implicit inspirations, music is made and consumed by people, and it reflects the conditions of that making and consumption.

In all but the rarest instances, musical works are scaled to the temporalities of the humans producing and receiving them. ${ }^{28}$ Music is, in this sense, an ode to humansizedness. The world is not populated with musical works that are .00632 seconds in length: this is the duration that a 3-minute pop tune would be if it were keyed not to the 72-year lifespan of a typical human but the 24-hour lifespan of an adult mayfly. Similarly, with the arguable exception of Cage and a small number of durational pieces by experimental artists, global music history is not awash in compositions of a length approaching 19 years, which is what a one-hour performance would be if it was keyed

Transposition, Hors-série 2| 2020 
to the ongoing life of the 500,000-year-old colony of actinobacteria recently discovered in Siberia. ${ }^{29}$ Moreover, the mayfly and the bacterium are, like many other nonhuman entities, ill-equipped even to perceive the vibrations that constitute musical sound. The list of earless creatures who live in muted or wholly soundless worlds is long. Music is manifestly not for them. ${ }^{30}$

Even for creatures who have ears, music's interspecies appeal is questionable. With very few exceptions, the undomesticated nonhuman realm appears to be profoundly unmoved by human-made musical sounds. ${ }^{31}$ Ants and coyotes and pigeons do not congregate around musical instruments when they are played; bears in the wild perceive music as one more index of a dangerous species that should be avoided if at all possible. The only animals who appear to have a real tolerance for music are those that live among humans-dogs, cats, cockatoos and other "companion species." 32 Your housecat's attraction to your piano playing thus has less to do with music's broad interspecies appeal, and more to do with music's participation in regimes of domestication and discipline that pull pets and agricultural animals in the direction of their human caregivers. (of course, if music does help to tame or "humanize" a domesticated animal, this only lends more credence to the solipsistic belief that we are distinct, autonomous agents capable of operating powerfully in, and on, the world.)

In most situations, music manifests as unwelcoming or inhospitable to nonhuman creatures. Unlike a sculpture upon which a bird can build its nest, unlike a painting or a book that can serve as a habitat for mold, music's vibratory materiality creates a sense of "home" that is designed exclusively for human habitation. Music disrupts animals' communicative channels. It is an exclusive gated playground whose structures were designed specifically for us. When placed within a broad environmental register that takes nonhuman life seriously, music reveals itself as a performance of exception.

\section{Centripetality}

41 Music reinforces human interiority, populating memory and imagination with an arresting archive of gestures, beats, textures, and feelings. Have you ever had an earworm stuck in your head, looping over and over independent of your will? Statistically, your answer will be yes. ${ }^{33}$ Now, be honest: have you ever had a painting, or a building, or a mathematical formula, or the sound of rustling leaves, or the absent smell of gasoline stuck in your head with the same persistent force as an earworm? Musical structures colonize the imagination and memory with unique force; they insistently demonstrate the presence and vitality of an inner world, an auditory imagination accessible to you alone. Imagined or remembered music portrays that inner world as active and dynamic: a vibrant, intimate, human-sized space of emotional encounter. When music is present in the imagination, your surroundings lose a bit of their sensory intensity and edge. (If they didn't, the earworm would disappear, incinerated by your fascination with the external world.) In this way, the auditory imagination tends to exert a centripetal force on perception, which can intensify a listener's embodied sense of their fictive separation from all that is not them. Cultural historian Josh Kun gave this kind of centripetal, music-saturated interiority a name: audiotopia. The audiotopia he discovered through listening to records as a child emplaced him within "my own world, ... an alternate set of cultural spaces that, through the private act of listening, could deliver me to different places and different 
times and allow me to try out different versions of my self." ${ }^{34}$ Though interior, audiotopias are by nature shared spaces, in which imagined communities of likeminded (human) listeners congregate. This audiotopic worlding capacity is what makes music such a powerful technology for creating and maintaining social identities.

Whether one is listening to music's public vibrations or silently experiencing music through imagination or memory, it is undeniable that a kind of embodied action is being performed. That action exists independently of the bodily movements that produce musical sounds (e.g., strumming a lute) or accompany them (e.g., dancing): the action is internal. Within a human-sized register, this internal action means something: it has spiritual, aesthetic, social, or other entailments. Musicking generates a sense of catharsis and fulfillment and feelingfulness. It triggers the release of endorphins that make us feel good inside. By generating these intoxicating sensations, music draws attention away from slow violence-a phenomenon that, because of its inhuman magnitude, is already impossible to fully grasp. The more riveting and beautiful music is, the greater its centripetality. Music's mesmerizing qualities cause expansive registers to collapse down to human size. ${ }^{35}$

\section{Instrumentality}

Consider the global music instrumentarium. Instrument makers throughout history have recruited a vast number of nonhuman bodies into the project of musicking, stripping them of their lives and ecological significance, and endowing them with a new "technosocial" role. ${ }^{36}$ Musical instruments have made use of elephant tusks, sheep intestines, horse hairs, tortoise shells, and the skins of an array of mammals from cows to goats to whales. Many species of trees have been brought to the brink of extinction by the production of musical instruments. The mining and refining of ore for metal, a common material in many instruments, poisons water supplies, devastates habitats, and often shortens the lives of the armies of workers who are involved in this industry. As we insistently pound on these carcasses and pluck these fibers and tickle these tusks we engage, unapologetically, in an incantatory display that theatrically, sonorously, and microcosmically presents humans as masters of a nonhuman world that exists for them alone. People derive neither physical sustenance nor shelter from these instruments. They construct them for the emotional, social and spiritual benefits that musicking produces. A positive feedback loop is established: the instrumentalization of the nonhuman world and the sensation of humans as soulful and exceptional creatures reinforce one another.

of course, some musical traditions do involve elaborate acknowledgment of the nonhuman sacrifices that went into the making of instruments, and the agencies instruments derive from their origins. Many indigenous communities treat instruments as "'beings', alive and sentient," for example ${ }^{37}$; and Yoruba traditions acknowledge the agencies trees have on the drums into which they are made. ${ }^{38}$ Western practices, and most contemporary music scenes globally, resolutely ignore these sacrifices. ${ }^{39}$ Tell the truth: when you listen to a recording of piano music do you ever find yourself thinking about the individual trees that were killed to make its body, much less the diverse ecology - the other trees, plants, birds, rodents, insects, humans, and potential spiritual entities-who were connected to and sustained by that tree? Do you think, when you hear the piano, of the oxygen that tree supplied and the atmospheric carbon it 
absorbed over the course of a life that might be measured in hundreds of years? Are you aware of the sheep whose wool made the felt of the hammers, or the copper ore buried deep in a mountain for millions of years before being extracted and refined into its strings, poisoning a river and leveling a forest in the process? If the piano was made before 1970, do you think of the elephants that were killed for their tusks to cover the keys, or of the abject economic conditions that compelled people to enter into the tuskharvesting trade? Do you think of the collection of human miners, lumberjacks, elephant poachers, sheep shearers, smelters, lacquer manufacturers, artisans, accountants, salespeople, et al., who participated in the making of a Steinway? Or of those laborers' many environmental entanglements and liabilities? ${ }^{40}$ I realize that most of the objects in our lives are similarly compromised. A car or leather couch or milk dud are all deeply entangled in this way. I am not suggesting that we need to strive for environmental purity in our lives ${ }^{41}$ But I do want to suggest that, within a disenchanted, empirical register that does not assign spiritual significance to instrumental origins, the sound of a piano beautifully played is remarkably good at obliterating thoughts about these hidden victims and participants. The sacrifices born by instrumentalized bodies are, for the music lover, so amply justified that they need not even be acknowledged. Music renders that violence inaudible.

If the material entanglements of musical instruments connect them to the humilibristic logics of slow violence, the history of their development and use within human registers strengthens this connection considerably. ${ }^{42}$ Music's involvement with organized killing is so profound that one could argue the two phenomena are coconstitutive. The bow loses its arrow and becomes the berimbau and a universal exciter of fiddle strings. The bone whistle enables communication among hunters and warriors alike. A type of magnetic tape developed for military use becomes a central technology for music recording. The drum and bagpipe are used to intimidate the enemy on the battlefield. Military service members construct "battle playlists" on their iPods to attain a hyperaggressive state before battle. The cacophony of modern warfare inspires Futurist musical experiments. Amplified music facilitates PSYOPS and "enhanced interrogation." Brass instruments decommissioned after the American Civil War facilitate the emergence of jazz. This well-documented history is often obscured within the phenomenological register of musical experience. Within the environmental register, by contrast, the connection between music, materiality, and violence in all of its multiplex forms is revealed as a throughline running from the beginning of the age of humans to the present.

\section{Reductivity}

There are, of course, moments when music is not directly referential to human thoughts and emotions, or operating in a tautological swirl of anthropocentric concerns. Music's mimetic capabilities allow it to reach out into the nonhuman world, to an extent. However, any mimetic translation of environmental entities or processes into music necessarily involves a radical reduction of their visual, tactile, olfactory, thermal, and other non-auditory dimensions. This is not to say that musicking itself isn't an intersensorial activity, involving bodies in motion, media, material, acoustic territories, and other real and imagined sensory stimuli along with the vibrations people call "sound." ${ }^{43}$ Rather, it is to say that music's representational capacity is 
concentrated within the sonorous realm. Put more crudely, a performance of Prokofiev's Peter and the Wolf may occasionally sound like a wolf or a duck, but it doesn't look or smell like a wolf or a duck. It smells like however the performers smell. Peter and the Wolf references the nonhuman world chiefly through sound.

Sound is good at depicting some aspects of more-than-human life: motion, emotion, copresence, rhythmicity, and texture, for example. (In fact, it is so good at these depictions that I imagine you can hear an appropriate musical gesture with each of the words on that list as you read them.) But it is not well-positioned to depict other aspects. Some of these, as I have discussed, have to do with the inhuman size and distended temporality of many environmental phenomena. Others involve sensory modalities that are simply incompatible with sound. Dirt on a carpet is easier to visualize than to hear, for example; toxicity, malodor, and rot are better smelled than listened to. One might compose a musical gesture that mimetically depicts a rising gaseous plume or an ocean wave, but how would one musically differentiate a plume of steam from a plume of smoke, or a pre-oceanic-acidification wave from a postacidification one? As a result of the sensory exclusivity of phenomena like dirt and toxicity and putrefaction, any musical depiction of environmental processes (especially slow violence) is almost certain to appear cleaner and therefore less complicated than the processes themselves. Music tends to simplify and cleanse the sullied environments it depicts.

Unlike the visual arts and architecture, whose materiality is always on display, the sonorous material of musicking is elusive. A painting or sculpture's material roots are undeniable and elemental; they can be seen, felt, sniffed, even tasted and made audible by a slap of the hand if you're bold enough. Not so with music, whose waves are invisible, ephemeral, and ungraspable. Music's reduction of worldly bodies to sound is in this sense a grand disappearing trick. Sound does have materiality of course, as the literature on acoustic violence amply attests. ${ }^{44}$ However, under most conditions, the musical sounds encountered over the course of human history have been auditory more than haptic, heard more than felt. This seeming immateriality allows musicking to embody and amplify the sensation of separation between human and nature that is at issue here. It is particularly powerful as a metonym for the "humble" component of humilibris discussed above. For unlike many other human enterprises, musicking appears to leave no environmental residue: the atmosphere has a seemingly infinite capacity to absorb musical vibrations and remain unchanged ${ }^{45}$ The changes wrought by musicking are social and emotional, and so take place within the scale of human individuals and groups, not environment. We are not surrounded by Chladni plates that render our musical vibrations visible. As a performance without palpable environmental consequences, music is capable of projecting an image of the human as inconsequential to nature.

\section{Siren}

You may have noticed that, in the latter half of this essay, I appear to have collapsed the environmental and phenomenological registers, drawing upon my personal experience of music as human-sized, centripetal, instrumentalizing, and sensorially reductive, and extrapolating these qualities to all music ever. Let me plead guilty to this charge, and point out some extenuating circumstances. It is unquestionably the case 
that, over the course of the 200,000-year era of musicking, many communities arose that did not frame the activity as enacting a cut that separates humans from nonhumans. ${ }^{46}$ (For what it's worth, however, I think we can read Tolbert and Tomlinson, minimally, as acknowledging the profound power of musicking on the formation of human-centered collectives over the entirety of human evolution.) It is also true that many listeners-detainees subjected to music torture, to take one obvious example-have perceived music as having a fundamentally inhuman size. ${ }^{47}$ It is likewise true that the "inner world" of imagined sound that I have outlined can be perceived, for listeners with different acoustemologies, as not "inner" at all: a voice or snippet of music stuck in one's head can be understood to be not "imagination" but "visitation," a social experience with a spiritual or distant corporeal interlocutor. In fact, as I have intimated all along, the qualities I attribute to music above do not in and of themselves create anthropocentric listeners. My claim is not that these qualities or affordances are totalizing or deterministic, but that, over time, their cumulative effect has been to subtly but consequentially amplify anthropocentric social structures and orientations, making them feel natural, intuitive, embodied, and real. And let's not forget that this naturalization takes place independent of the labor performed by the words of song lyrics and the intensely human sound of the singing voice. I will leave it to you, reader, to think back on all of the sung music you have ever heard, and decide whether or not the preponderance of it emphasizes narrowly human concerns, or environmental entanglements.

Within the deeply anthropocentric milieu of global modernity, one can make a stronger case for music's cumulative effect. In postindustrial life, music regularly guides, compresses, domesticates, harmonizes, humanizes thought. Musicking cathects "world," and it continues to project this humanized, audiotopic image of world, even if "the concept of world is no longer operational." It does so by drawing listeners' thoughts and bodies into a centripetal, human register of willful action and social relations, and away from the (centrifugal) environmental registers of more-than-human relationality and radical entanglement. Over the course of modern history, musicking has given voice to a multitude of perspectives-but in the end it has sung most convincingly a siren song, a song of separation from the buzzing, biting, vulnerable environment of which we are a constituent part. That sense of separation, widely dispersed and wildly durable, has been weaponized by some human collectives to recast creatures as resources, pollution as oblivion, and immiseration as progress. In other words, musicking may not have caused the end of the world, but it did provide it with an intoxicating soundtrack. ${ }^{48}$

\section{Thriving}

51 What, in the end, is one to do with the heretical notion that musicking may somehow have facilitated the slow violence of anthropogenic pollution and global warming? I honestly don't know what you should do, but here are my personal urges: first, I wantI need-to continue cherishing the music that helps me and my loved ones thrive, regardless of the humilibristic potentialities that music may harbor. Life continues after the end of the world, and human thriving cannot be taken for granted within it; as we (in the radically inclusive sense of that word) move into an unstable future we are going to need all the help we can get. I may continue to imaginatively project myself 
into an environmental register, but I live in a human-sized one, along with you and many others, and that is where music reveals its deepest potential to create meaning and sustain life.

At the same time, I want to work to better understand and support communities whose musical practices explicitly contradict the humilibristic logics of anthropocentrism, promoting ideologies and aesthetics of relation and connection instead of separation and transcendence. Many of these practices are indigenous or non-Western; others are associated with one avant garde movement or another. All are experimental, in the sense that they propose aesthetics and ontologies of sound that come into conflict with hegemonic musical norms. As such, these musics have the potential to illuminate an urgent truth: that human thriving is not independent of environmental thriving-in fact, they are the same thing. ${ }^{49}$ If ethnomusicology and ecomusicology have a profound contribution to make in the 21st century, it surely involves continuing to bring grounded knowledge of these traditions to a broad postindustrial audience. They will need to do this not so as to complete an exhaustive catalogue of human musical diversity, and not merely to draw attention to the plight of marginalized peoples and the many forms of violence they endure, but also in order to provide real, creative, alternative models for imagining the ties that join bodies-all bodies, everybodytogether. At the same time, these disciplines and their readerships will need to respect a community's right to keep some registers private, and accept that some practices are site-specific, and not open to export or exploitation..$^{50}$

A growing amount of work in music and sound studies has begun deconstructing human/nature dualism-by emphasizing music's intersensoriality and relationality (e.g., Eidsheim, Kapchan), decolonizing discourse on musical ontologies (e.g., Sykes), or exploring how music's invisible vibrations are inseparable from the material consequences of its "technosocial" underpinnings (e.g., Devine)..$^{51}$ By reflecting critically upon music's "exclusive," "centripetal," "instrumental," and "reductive" potentialities, I hope to have contributed to this project in a small way. I further hope that this essay will help you imagine-or remember-music that is radically inclusive, centrifugal, transcorporeal, and irreducible.

of course, if one listens awry or against the grain, all music can be heard-or made-to testify on behalf of environmental entanglement..$^{52}$ (My posthuman narration of the Yamashita concert at the beginning of the essay was an attempt to do just this.) What would music studies look like if it treated music as one ecological sound among others, one more interspecies choreography of bodies, one more perturbation of the biosphere? The challenge would be to do this without simply pulling the environment into a ready-made aesthetic frame, "tuning the world" by "treat[ing it] ... as a macrocosmic musical composition." ${ }^{53}$ Adopting an environmental register such as the one I have proposed here would radically decenter the human and defamiliarize our songs. It would open up the floodgates and allow the myriad sonic praxes of nonhuman species, long held at bay by the anthropocentric term "music," to come rushing into our considerations, overwhelming our human-centered auditory regimes and forcing us to sink or swim in the turbulent waters of more-than-human expression.

55 If the foregoing few paragraphs make you think I am bringing this reflection on music and slow violence to an optimistic, even utopian, conclusion, don't be fooled. Near the beginning of this essay, I mentioned the "asymmetry and temporal dynamism" of our environmental entanglements, and the unequal stakes they produce for the human and 
nonhuman bodies involved. We (radically inclusive) are at the mercy of this asymmetry now. Recall my thesis: the cumulative effect of music on the environment has been to subtly reinforce the humilibristic worldview that made industrial-scale environmental violence thinkable. This process could only have taken place slowly, incrementally, over centuries, in multiple regions across the planet. If people agree to acknowledge the more-than-human voices that permeate and surround all music, then might music itself be deployed to facilitate a turn away from anthropocentrism, and with it, a global commitment to repair the environmental wounds of industrial modernity? Lamentably, no: there isn't enough time for slow violence to be undone by slow enlightenment. We don't have hundreds of years of climate stability left to allow that process to unfold. Given this temporal asymmetry, there can be no musical strategy for combatting climate change. Any deployment of music will always be a tactic of the weak (de Certeau), whose effects will only be palpable in local, social registers. Music has many potentialities: reinforcing humilibris in human bodies and collectives slowly over time is one of them; saving the world from environmental cataclysm is not. The idea of music-centered salvation is made even more unthinkable by the growing acceleration of environmental instability over the past several years. Music as an environmental force remains slow; climate no longer is.

In the midst of this grim state of affairs, I find myself engaging in senseless, Quixotic musical undertakings. They bear scant resemblance to the burgeoning and impressive corpus of climate-themed compositions and environmental sound art, which I admire and try to patronize. ${ }^{54}$ I think of them as small Borgesian provocations, aimed at the heart of the era Amitav Ghosh calls "the Great Derangement." Ghosh imagines that future humans will look back aghast at our current time, "when most forms of art and literature were drawn into ... modes of concealment that prevented people from recognizing the realities of their [environmental] plight.." ${ }^{55}$ My little pieces are designed to scratch through these concealing modes. To be clear, they are utterly ineffectual out in the world, but I find them strangely therapeutic-tactically, locally, for myself and perhaps my family and a few friends-especially when the abyss looms. With my colleague Joel Rust, I have begun composing operas for adult mayflies: halfsecond-long, soft, low-pitched gesamtkunstwerke to accompany their all-encompassing sex acts without taking up too much of their brief lives. I've also started writing a decade-long, heartbreaking torch song for the Siberian actinobacteria, a piece which, even if performed, they would never be able to hear. I walk around my neighborhood trying to turn birdsong and industrial sounds into earworms that loop and repeat in my memory as insistently as music does. I struggle to imagine musical sounds that smell of dirt and smoke and taste like acidifying oceans and car exhaust. I have crafted a requiem for the trees, mountains, elephants, habitats, shorn sheep, displaced fauna, smelting plants, copper miners, and poisoned lungs that are buried inside my old upright piano. This piece is simultaneously a paean to artisans, composers, music teachers, students, prodigies, hacks, audience members, piano movers and tuners and dusters-and to the vibrations, relations, emotions, revelations, and audiotopias that regularly visit the musicking masses. To most listeners, my piece would be indistinguishable from John Cage's famous composition 4'33". Except that this piece's duration is not four-and-a-half minutes but four-and-a-half billion years, the period at the end of which the sun will begin expanding on its Red Giant path to incinerate the inner solar system, marking a final, conclusive coda for all of our earthly performances. 
${ }^{56}$ The piece is up and running now-can you hear it? It is titled "The Piano Is Always Burning." This title is, I think, a good mantra for understanding all music ever.

Speaking of burning pianos, I have often thought of how the 2008 performance of "Burning Piano" must have played out on the beach in Japan after the cameras and recorders were turned off. Did it create a fragile sense of music's profound environmental entanglements for the audience? If so, how long was it before the human-scaled, centripetal pleasures of musicking retook the foreground? In my imagination, it went something like this:

\section{Fragility}

58 Eventually, the crowd began to disperse. Yamashita's lungs continued to contend with the smoke that had threatened to overwhelm them. He coughed again as he retreated farther along the beach, and felt his cheeks with his fingers; both were tender from the heat. The performance he initiated continued to smolder according to inhuman rules, slowly tracing its asymptotic decrescendo into the air. A solitary bird flapped by, encountered the blurred edge of the smoke plume, and altered its course in response. The audience members moved away from the scene and toward their cars in the parking lot. Starting them up, they initiated a series of unending combustion performances, adding a few more layers to the planet's palimpsestic archive. Smoke (a.k.a. piano, tree, mountain, sheep) clung to the fibers of their clothes, slowly infusing the air inside the cars as they turned, one by one, onto the coastal road.

One of the drivers switched on her car radio; it was tuned to Radio Hayama, a jazz station that had been playing Yamashita's classic 1975 album Breathtake on the way out to the beach. Now, Ella Fitzgerald was midway through an achingly slow and soulful rendition of an old Cole Porter number. ${ }^{57}$ Her voice, accompanied by Tommy Flanagan on piano and bearing the traces of six decades of use, flooded the car:

When you're near

There's such an air of spring about it.

I can hear a lark somewhere

Begin to sing about it.

Something about the song, coming right on the heels of "Burning Piano," ushered the driver into a kind of surreal reverie. Fitzgerald's breathy voice and the thin trail of piano smoke in the distance briefly appeared to fuse together in her mind, smoke and sound pointing equally to the fragility of bodies within the vastness of air. Her familiar surroundings took on an uncanny aspect, as the smoke, and the road, and the voice, and the pianos (Flanagan's and Yamashita's) began to tangle in her imagination. The clear lines once separating them had vanished. Fitzgerald's voice-or was it the smoke plume?-sang:

There's no love song finer

But how strange the change from major to minor

61 She felt time stretching, an abyss opening up, a brief wave of vertigo. A precarious future appeared to loom before her, dark as the encroaching dusk, and her sense of fragility and entanglement grew. Fukushima was still three years off, so she couldn't have been thinking about that. So too were Hurricane Sandy, Deepwater Horizon, the Syrian conflict, the climateinfluenced migration crisis, deadly heat waves across Europe and South Asia, the South African water shortage, and a billion animals dead in the Australian wildfires of 2019-20. She thought of none of these. Rather, a vague, rootless sense of foreboding enveloped her as the voice reached the last line of the chorus: 
Every time we say goodbye.

And then the song ended, and was replaced by a news update. The car continued down the road. As the final cadence resolved and died out, the driver's brief moment of dread subsided. Fitzgerald's last phrase, now looping slowly in the driver's imagination, smoothly and methodically wiped out her memory of the entire surreal episode. "What a beautiful voice," she whispered, as, on the horizon, the last vestige of piano disappeared into air.

\section{BIBLIOGRAPHY}

ADEGBITE Ademola, “The Drum and Its Role in Yoruba Religion”, Journal of Religion in Africa, vol. 18, no. 1,1988 , pp. 15-26.

ALAIMo Stacy, Bodily Natures: Science, Environment, and the Material Self, Bloomington, Indiana University Press, 2010.

BARAD Karen, Meeting the Universe Halfway: Quantum Physics and the Entanglement of Matter and Meaning, Durham, Duke University Press, 2007.

BARTHES Roland, Image, Music, Text, London, Fontana Press, 1977.

BLACKING John, How Musical is Man?, Seattle, University of Washington Press, 1973.

BOURDIEU Pierre and WACQUANT Loïc J. D., An Invitation to Reflexive Sociology, Chicago, University of Chicago Press, 1992.

BOWmAn A. et al., “'Four Seasons' in an Animal Rescue Centre: Classical Music Reduces Environmental Stress in Kennelled Dogs”, Physiology and Behavior, vol. 143, 2015, pp. 70-82.

BRABEC DE MORI Berndt, "Music and Non-Human Agency”, POST Jennifer (ed.), Ethnomusicology: A Contemporary Reader, vol. II, New York and London, Routledge, 2017, pp. 181-194.

CHAUDHURI Una, The Stage Lives of Animals: Zooesis and Performance, New York, Routledge, 2016.

COLEBROOK Claire, "Fragility, Globalism, and the End of the World", lecture at Yale University, 2017 (https://www.youtube.com/watch?v=_loQpyu84WA, consulted on 27 February 2020).

CRUIKSHANK Julie, Do Glaciers Listen? Local Knowledge, Colonial Encounters, and Social Imagination, Vancouver, University of British Columbia Press, 2005.

CUSICK Suzanne, “'You Are In a Place That Is Out of the World . . '? Music in the Detention Camps of the 'Global War on Terror"', Journal of the Society for American Music, vol. 2, no. 1, 2008, pp. 1-26. DASTON Lorraine, "Objectivity and the Escape from Perspective”, Social Studies of Science, vol. 22, no. 4, 1992, pp. 597-618.

DAUGHTRY J. Martin, “Thanatosonics: Ontologies of Acoustic Violence," Social Text, vol. 32, no. 2 (119), 2014, pp. 25-51.

DAUGHTRY J. Martin, Listening to War: Sound, Music, Trauma, and Survival in Wartime Iraq, New York, Oxford University Press, 2015. 
DAUGHTRY J. Martin, "Listening Beyond Sound and Life: A Fragile Phenomenology of the Auditory Imagination", BERGER Harris and SZEGo Kati (eds.), The Oxford Handbook of Phenomenological Ethnomusicology, New York, Oxford University Press, forthcoming.

DEVINE Kyle, Decomposed: The Political Ecology of Music, Cambridge (MA), MIT Press, 2019.

DIAMOND Beverley, CRONK M. Sam and VON ROSEN Franziska, Visions of Sound: Musical Instruments of First Nations Communities in Northeastern America, Chicago, University of Chicago Press, 1994.

DIBERNARDO JONES Jeannette, “Imagined Hearing: Music-Making in Deaf Culture”, HowE Blake et al. (eds.), The Oxford Handbook of Music and Disability Studies, New York, Oxford University Press, 2016, 10.1093/oxfordhb/9780199331444.013.3.

DIRKSEN Rebecca, “Haiti’s Drums and Trees: Facing Loss of the Sacred”, Ethnomusicology, vol. 63, no. 1, 2019, pp. 43-77.

DROBNICK Jim, “Listening Awry”, DROBNICK Jim (ed.), Aural Cultures, Toronto, YYZ Books, 2004, pp. 9-15.

EIDSHEIM Nina, Sensing Sound: Singing and Listening as Vibrational Practice, Durham, Duke University Press, 2015.

FELD Steven, Sound and Sentiment: Birds, Weeping, Poetics, and Song in Kaluli Expression, Durham, Duke University Press, 2012 [1982].

FLUSSER Vilém, “Orders of Magnitude and Humanism", Writings, translated by Elizabeth Wilson and Andreas Ströhl (ed.), Minneapolis, University of Minnesota Press, 2004, pp. 160-164.

FRIEDSON Steven, Remains of Ritual: Northern Gods in a Southern Land, Chicago, University of Chicago Press, 2009.

GAONKAR Dilip, ed. Alternative Modernities, Durham, Duke University Press, 2001.

GHOSH Amitav, The Great Derangement: Climate Change and the Unthinkable, Chicago, University of Chicago Press, 2016.

GRANT Morag, "On Music and War," Transposition, no. Hors-série 2, 2020, 2020, https://doi.org/ 10.4000/transposition.4469.

HARAWAY Donna, The Companion Species Manifesto: Dogs, People, and Significant Otherness. Chicago, Prickly Paradigm Press, 2003.

KAPCHAN Deborah, "The Splash of Icarus: Theorizing Sound Writing / Writing Sound Theory", KAPCHAN Deborah (ed.), Theorizing Sound Writing, Middletown (CT), Wesleyan University Press, 2017, pp. 1-22.

KUN Josh, Audiotopia: Music, Race, and America, Berkeley, University of California Press, 2005.

LATOUR Bruno, Reassembling the Social: An Introduction to Actor-Network-Theory, New York, Oxford University Press, 2005.

LEVINE Victoria and ROBINSON Dylan (eds.), Music and Modernity among First Peoples of North America, Middletown (CT), Wesleyan University Press, 2019.

MALKKI Liisa H., Purity and Exile: Violence, Memory, and National Cosmology among Hutu Refugees in Tanzania, Chicago, University of Chicago Press, 1995. 
MALM Andreas, “The Anthropocene Myth”, Jacobin, 30 March 2015, (https://

www.jacobinmag.com/2015/03/anthropocene-capitalism-climate-change/, consulted on 27 February 2020).

MANABE Noriko, The Revolution Will Not Be Televised: Protest Music after Fukushima, New York, Oxford University Press, 2015.

MORTON Timothy, Hyperobjects: Philosophy and Ecology after the End of the World, Minneapolis, University of Minnesota Press, 2013.

NIXON Rob, Slow Violence and the Environmentalism of the Poor, Cambridge (MA), Harvard University Press, 2011.

o'CONNELL John Morgan and CASTELO-BRANCo Salwa el-Shawan (eds.), Music and Conflict, Urbana, University of Illinois Press, 2010.

OCHOA GAUTIER Ana María, "Acoustic Multinaturalism, the Value of Nature, and the Nature of Music in Ecomusicology", Boundary 2, vol. 43, no. 1, 2010, pp. 107-141.

PAPAETI Anna, "Music, Torture, Testimony: Reopening the Case of the Greek Military Junta (1967-1974)”, The World of Music (New Series), vol. 2, no.1, 2013, pp. 67-90.

PETTAN Svanibor (ed.), Music, Politics, and War: Views from Croatia, Zagreb, Institute of Ethnology and Folklore Research, 1998.

PLumwood Val, The Eye of the Crocodile, edited by Lorraine Shannon, Acton, Australian University Press, 2012.

POST Jennifer C., "Climate Change, Mobile Pastoralism, and Cultural Heritage in Western Mongolia”, cooley Timothy J. (ed.), Cultural Sustainabilities: Music, Media, Language, Advocacy, Urbana, University of Illinois Press, 2019, pp. 75-86.

PRIEST Eldritch, "Earworms, Daydreams, and Cognitive Capitalism", Theory, Culture \& Society, vol. 35, no. 1, 2018, pp. 141-162.

REED Trevor, "Pu-Itaaqatsit aw Tuuqayta (Listening to Our Modern Lives)", LEVINE Victoria and ROBINSON Dylan (eds.), Music and Modernity among First Peoples of North America, Middletown (CT), Wesleyan University Press, 2019, pp. 258-264.

REES Helen, “Environmental Crisis, Culture Loss, and a New Musical Aesthetic: China's 'Original Ecology Folksongs"', Ethnomusicology, vol. 60, no. 1, 2016, pp. 53-88.

RODA Allen, “Tabla Tuning on the Workshop Stage: Toward a Materialist Musical Ethnography”, Ethnomusicology Forum, vol. 23, no. 3, 2014, pp. 360-382.

ROTHENBERG David, Thousand-Mile Song: Whale Music in a Sea of Sound, New York, Basic Books, 2010.

SAKAKEENY Matt, Roll With It: Brass Bands in the Streets of New Orleans, Durham, Duke University

Press, 2013.

SCHAFER R. Murray, Soundscape: Our Sonic Environment and the Tuning of the World, Rochester (VT), Destiny Books, 1994 [1977].

SCHWARTZ Jessica, “A 'Voice to Sing': Rongelapese Musical Activism and the Production of Nuclear Knowledge”, Music \& Politics, vol. 6, no. 1, 2012, https://dx.doi.org/10.3998/mp.9460447.0006.101. SEEGER Anthony, Why Suyá Sing: A Musical Anthropology of an Amazonian People, Champaign (IL), University of Illinois Press, 2004 [1987]. 
SHOTWELL Alexis, Against Purity: Living Ethically in Compromised Times, Minneapolis, University of Minnesota Press, 2016.

SORCE KELLER Marcello, “Zoomusicology and Ethnomusicology: A Marriage to Celebrate in Heaven”, Yearbook for Traditional Music, vol. 44, 2012, pp. 166-183.

STRYKER Noah, The Thing with Feathers: The Surprising Lives of Birds and What They Reveal About Being Human, New York, Riverhead Books, 2015.

SYKES Jim, “The Anthropocene and Music Studies," Ethnomusicology Review, vol. 22, no. 1, 2019, pp. 4-21.

TOLBERT Elizabeth, “Music and Meaning: An Evolutionary Story”, Psychology of Music, vol. 29, no. 1, 2001, pp. 84-94.

TOMLINSON Gary, A Million Years of Music: The Emergence of Human Modernity, New York, Zone Books, 2015.

TSING Anna Lowenhaupt, The Mushroom at the End of the World: On the Possibility of Life in Capitalist Ruins, Princeton, Princeton University Press, 2015.

TSING Anna Lowenhaupt et al. (eds.), Arts of Living on a Damaged Planet: Ghosts and Monsters of the Anthropocene, Minneapolis, University of Minnesota Press, 2017.

VIVEIROS DE CASTRo Eduardo, Cannibal Metaphysics, translated and edited by Peter Skafish, Minneapolis, Univocal, 2014 [2009].

WIEVIORKA Michel, "Violence and the Subject", Thesis Eleven, vol. 73, no. 1, 2003, pp. 42-50.

WOLFE Cary, What is Posthumanism?, Minneapolis, University of Minnesota Press, 2009.

\section{NOTES}

1. YAMASHITA Y ōsuke, "Burning Piano", 2008 ( https://www.youtube.com/watch? $\mathrm{v}=$ YpKT_eeCVNI\& $\mathrm{t}=1 \mathrm{~s}$, consulted on 27 February 2020).

2. This counterintuitive thought was born in conversation with the composer Joel Rust.

3. ALAimo Stacy, Bodily Natures: Science, Environment, and the Material Self, Bloomington, Indiana University Press, 2010.

4. BARAD Karen, Meeting the Universe Halfway: Quantum Physics and the Entanglement of Matter and Meaning, Durham, Duke University Press, 2007.

5. See for example MALKKI Liisa H., Purity and Exile: Violence, Memory, and National Cosmology among Hutu Refugees in Tanzania, Chicago, University of Chicago Press, 1995; PETTAN Svanibor (ed.), Music, Politics, and War: Views from Croatia, Zagreb, Institute of Ethnology and Folklore Research, 1998; cusick Suzanne, “'You Are In a Place That Is Out of the World...': Music in the Detention Camps of the "Global War on Terror", Journal of the Society for American Music, vol. 2, no. 1, 2008, pp. 1-26; o'Connell John Morgan and CASTElo-Branco Salwa el-Shawan (eds.), Music and Conflict, Urbana, University of Illinois Press, 2010; PAPAETI Anna, "Music, Torture, Testimony: Reopening the Case of the Greek Military Junta (1967-1974)", The World of Music (New Series), vol. 2, no.1, 2013, pp. 6790; DAUGHTRY J. Martin, Listening to War: Sound, Music, Trauma, and Survival in Wartime Iraq, New York, Oxford University Press, 2015.

6. My thinking on the importance of scales and registers owes a great debt to conversations I've had with Jairo Moreno and Mike Beckerman over the years. 
7. See for example DASTON Lorraine, "Objectivity and the Escape from Perspective", Social Studies of Science, vol. 22, no. 4, 1992, pp. 597-618; FLUSSER Vilém, "Orders of Magnitude and Humanism", Writings, translated by Elizabeth Wilson and Andreas Ströhl (ed.), Minneapolis, University of Minnesota Press, 2004, pp. 160-164; and BARAD, Meeting the Universe Halfway.

8. Vilém Flusser uses the matryoshka or Russian nesting doll as a metaphor for this irreducible complexity, arguing that we are always-already embedded within, and susceptible to, all "orders of magnitude" at once; see FLUSSER, "Orders of Magnitude and Humanism". Symbolic violence thus occurs when this holistic scenario is reduced to a single order of magnitude or register. Decades earlier, in the mid-20th century, Fernand Braudel and other members of the Annales school began writing histories that were arrayed along multiple temporal scales. One of these was the longue durée, a scale measured in centuries or millennia that captured slow environmental, geographical, and demographical processes.

9. Most of the human-sized registers scholars have used to frame music have participated in what Nina Sun Eidsheim calls "the figure of sound," a complex of naturalized tropes dealing with the correlation of sound, music, and human listeners. Together, these tropes amount to a default acoustemology that reduces the intersensoriality of sound to a more or less static aesthetic object (see EIDSHEIM Nina, Sensing Sound: Singing and Listening as Vibrational Practice, Durham, Duke University Press, 2015).

10. BouRdieu Pierre and Wacquant L. J., An Invitation to Reflexive Sociology, Chicago, University of Chicago Press, 1992.

11. For more on hot and cold violence, see WIEvioRKA Michel, "Violence and the Subject", Thesis Eleven, vol. 73, no. 1, 2003, pp. 42-50.

12. NIXON Rob, Slow Violence and the Environmentalism of the Poor, Cambridge (MA), Harvard University Press, 2011, p. 2, my emphasis.

13. For a discussion of "the gap between phenomenon and thing," or the difference between an imperceptible process like global warming and the perceptible effects of that process, see MORTON Timothy, Hyperobjects: Philosophy and Ecology after the End of the World, Minneapolis, University of Minnesota Press, 2013, pp. 47-51.

14. See for example DIRKSEN Rebecca, "Haiti's Drums and Trees: Facing Loss of the Sacred", Ethnomusicology, vol. 63, no. 1, 2019, pp. 43-77; MANABE Noriko, The Revolution Will Not Be Televised: Protest Music after Fukushima, New York, Oxford University Press, 2015; REES Helen, "Environmental Crisis, Culture Loss, and a New Musical Aesthetic: China's 'Original Ecology Folksongs'," Ethnomusicology, vol. 60, no. 1, 2016, pp. 53-88; SAKAKEENY Matt, Roll With It: Brass Bands in the Streets of New Orleans, Durham, Duke University Press, 2013; SCHWARTZ Jessica, "A 'Voice to Sing': Rongelapese Musical Activism and the Production of Nuclear Knowledge”, Music \& Politics, vol. 6, no. 1, 2012, https://dx.doi.org/10.3998/mp.9460447.0006.101.

15. MORTON, Hyperobjects, p. 6.

16. соLевRоок Claire, "Fragility, Globalism, and the End of the World", lecture at Yale University, 2017 (https://www.youtube.com/watch?v=_loQpyu84WA, consulted on 27 February 2020).

17. TOLBERT Elizabeth, "Music and Meaning: An Evolutionary Story", Psychology of Music, vol. 29, no. 1, 2001, pp. 86-87, my emphases.

18. GRANT Morag, “On Music and War", Transposition, hors-série 2, 2020, https://doi.org/10.4000/ transposition.4469, my emphasis.

19. TOMLINSON Gary, A Million Years of Music: The Emergence of Human Modernity, New York, Zone Books, 2015 pp. 48-49, author's emphasis.

20. Ibid., p. 50, my emphasis.

21. This is one of the principal critiques of the term "anthropocene": namely, that it implies that the entire human species is responsible for global warming, and therefore that there is no difference between the activities of a rural goatherder and an international oil magnate. For a 
powerful argument in favor of the term "capitalocene," see MALm Andreas, "The Anthropocene Myth", Jacobin, 30 March 2015 (https://www.jacobinmag.com/2015/03/anthropocene-capitalismclimate-change, consulted on 27 February 2020).

22. Plumwood Val, The Eye of the Crocodile, edited by Lorraine Shannon, Acton, Australian University Press, 2012, p. 15.

23. In doing so, this work fails to recognize the contributions of the vibrant group of scholars working under the rubric of perspectivism and/or in the environmental humanities and animal studies. These intellectual movements are committed to dismantling the anthropocentric framework that has undergirded the humanities for centuries. See for example VIVEIROS DE CASTRO Eduardo, Cannibal Metaphysics, translated and edited by Peter Skafish, Minneapolis, Univocal, 2014 [2009]; TSING Anna Lowenhaupt, The Mushroom at the End of the World: On the Possibility of Life in Capitalist Ruins, Princeton, Princeton University Press, 2015; CHAUDHURI Una, The Stage Lives of Animals: Zooesis and Performance, New York, Routledge, 2016; TSING Anna Lowenhaupt et al. (eds.), Arts of Living on a Damaged Planet: Ghosts and Monsters of the Anthropocene, Minneapolis, University of Minnesota Press, 2017; Plumwood Val, The Eye of the Crocodile; and wolfe Cary, What is Posthumanism?, Minneapolis, University of Minnesota Press, 2009. Within music studies, scholars working in an ethnographic register with indigenous communities have long contributed to the critique of anthropocentrism. See for example FELD Steven, Sound and Sentiment: Birds, Weeping, Poetics, and Song in Kaluli Expression, Durham, Duke University Press, 2012 [1982]; SEEGER Anthony, Why Suyá Sing: A Musical Anthropology of an Amazonian People, Champaign (IL), University of Illinois Press, 2004 [1987]; DIAMOND Beverley, CRONK M. Sam and VON ROSEN Franziska, Visions of Sound: Musical Instruments of First Nations Communities in Northeastern America, Chicago, University of Chicago Press, 1994; CRUIKSHANK Julie, Do Glaciers Listen? Local Knowledge, Colonial Encounters, and Social Imagination, Vancouver, University of British Columbia Press, 2005; BRABEC DE MORI Berndt, "Music and Non-Human Agency", Post Jennifer (ed.), Ethnomusicology: A Contemporary Reader, vol. II, New York and London, Routledge, 2017, pp. 181-194; and LEVINE Victoria and ROBINSON Dylan (eds.), Music and Modernity among First Peoples of North America, Middletown (CT), Wesleyan University Press, 2019.

24. осHоA GAUTIER Ana María, "Acoustic Multinaturalism, the Value of Nature, and the Nature of Music in Ecomusicology", Boundary 2, vol. 43, no. 1, 2010, p. 125.

25. Ibid., p. 127.

26. For an influential study of alternative modernities, see GAONKAR Dilip (ed.), Alternative Modernities, Durham, Duke University Press, 2001.

27. As Marcello Sorce Keller has written, "There are things that non-human animals apparently never do. [...T] he embedding of words in a melody, following a metrical pattern, appears to be uniquely human" (2012, p. 176, quoted in BRABEC DE MORI, "Music and Non-Human Agency", p. 183.

28. Take for example John Cage's ASLSP (as slow as possible), a 639-year-long piece for unmanned pipe organ, currently being performed in Halberstadt, Germany (https://universes.art/en/ specials/john-cage-organ-project-halberstadt, consulted on 27 February 2020).

29. In 2014, as part of an exhibition at the New Museum in Manhattan, Icelandic artists Ragnar Kjartansson and Kjartan Sveinsson organized a performance of "Take Me Here by the Dishwasher: Memorial for a Marriage," a short piece for live musicians, which was repeated continuously during the museum's open hours throughout the exhibition. The total performance lasted for roughly 360 hours, spread out over more than a month.

30. Mayflies have antennae that may pick up some low-frequency vibrations that are audible to most humans. Actinobacteria have no such mechanisms. If a mayfly cannot perceive vibrations above $100 \mathrm{hz}$, then a mayfly-sized pop tune would be physically inaudible by any creature, as it would be much shorter in length than a single cycle at that frequency. An extended mayfly 
opera, roughly equivalent in duration to Wagner's Die Meistersinger for humans, would register as about a half-second of sound.

This observation is not in any way intended to dismiss the vibrant culture of human "Deaf listening" that has been recently documented by scholars of disability studies. See for example DIBERNARDO JONES Jeannette, "Imagined Hearing: Music-Making in Deaf Culture”, howE Blake et al. (eds.), The Oxford Handbook of Music and Disability Studies, New York, Oxford University Press, 2016, 10.1093/oxfordhb/9780199331444.013.3.

31. For a discussion of the parameters of animal tolerance of and/or attraction to human musicking, see STRYKER Noah, The Thing with Feathers: The Surprising Lives of Birds and What They Reveal About Being Human, New York, Riverhead Books, 2015; ROTHENBERG David, Thousand-Mile Song: Whale Music in a Sea of Sound, New York, Basic Books, 2010; and BowMAN A. et al., "'Four Seasons' in an Animal Rescue Centre: Classical Music Reduces Environmental Stress in Kennelled Dogs", Physiology and Behavior, vol. 143, 2015, pp. 70-82.

32. HARAWAY Donna, The Companion Species Manifesto: Dogs, People, and Significant Otherness, Chicago, Prickly Paradigm Press, 2003.

33. While the ubiquity of digital music in public and private spaces has certainly exacerbated this phenomenon for people in post-industrial societies, ample evidence exists that the "earworm" predates the era of recorded sound. The repetition of music in ritualized contexts from work to worship has for millennia created opportunities for songs to lodge in people's imaginations and memories. For a provocative analysis of earworms, see PRIEST Eldritch, "Earworms, Daydreams, and Cognitive Capitalism," Theory, Culture \& Society, vol.35, no. 1, 2018, pp.141-162. For a phenomenological account of the auditory imagination, see DAUGHTRY J. Martin, "Listening Beyond Sound and Life: A Fragile Phenomenology of the Auditory Imagination", BERGER Harris and SZEGo Kati (eds.), The Oxford Handbook of Phenomenological Ethnomusicology, New York, Oxford University Press, forthcoming.

34. KUN Josh, Audiotopia: Music, Race, and America, Berkeley, University of California Press, 2005, p. 2.

35. I thank Kati Szego for guiding me toward this thought.

36. TOMLINSON Gary, A Million Years of Music.

37. DIAMOND et al., Visions of Sound, p. 6.

38. ADEGBITE Ademola, "The Drum and Its Role in Yoruba Religion", Journal of Religion in Africa, vol. 18 , no. 1, 1988, pp. 15-26.

39. The instrumentalization of the world takes place in many musical contexts globally. Steven Friedson's account of the brekete drum made for him by his Ewe colleagues in Ghana makes this clear: "Any used metal barrel about two to two and a half feet long will do-mine had stickers on it picturing an umbrella with raindrops and the warning 'Dangerous When Wet'-as long as it can produce the requisite sound. What is significant about a brekete drum is the fact that it has been consecrated, thus activated. The drum I was playing had been given drink, had been fed with the blood of several chickens, and contained Kunde's kaolin and kola." (FRIEDSON Steven, Remains of Ritual: Northern Gods in a Southern Land, Chicago, University of Chicago Press, 2009, p. 124). Spiritual practices that infuse instruments with energy and even consciousness often treat raw environmental material in the same way as Steinway manufacturers: as a means to an end. I am grateful to Beverley Diamond for alerting me, in conversation, to a number of indigenous counterexamples where communities acknowledge the identity of the entities that make up a musical instrument.

40. This part of the essay tracks closely with the methodologies of Actor Network Theory-for a classic in the genre, see LATOUR Bruno, Reassembling the Social: An Introduction to Actor-NetworkTheory, New York, Oxford University Press, 2005; also, for an Actor Network-influenced analysis 
of a single musical instrument, see RODA Allen, "Tabla Tuning on the Workshop Stage: Toward a Materialist Musical Ethnography", Ethnomusicology Forum, vol. 23, no. 3, 2014, pp. 360-382.

41. For a critique of ideologies of purity see SHотwell Alexis, Against Purity: Living Ethically in Compromised Times, Minneapolis, University of Minnesota Press, 2016.

42. Daniel Oore recently drew my attention to this aspect of the music-violence relationship.

43. See EIDSHEIM Nina, Sensing Sound, for an extended discussion of the intersensoriality of music.

44. In the active combat zones of the Iraq war, "people listened with their ears-but also with their skin, their chest cavities, the hair on the back of their necks, their viscera. The loud sounds of weaponry regularly bled into the realm of the haptic when they were this close up. When they were even closer, and even louder, these sounds lost their capacity to serve as a resource, a text to be interpreted, an illuminating index of a nearby violent act: at the closest distances, the loudest sounds assaulted bodies, and they often did so before any tactical judgment or meaningful interpretation could possibly be made" (DAUGHTRY, Listening to War, p. 92).

45. Despite appearances, musical vibrations do have a small but real effect on atmosphere. Like all other mechanical vibrations, music incrementally raises the temperature of the medium through which it passes. The atmosphere, in other words, treats sound as heat. The amount of heat sound creates is negligible, however, and not part of any scientific understanding of global warming. I thank Tyler Volk for this insight.

46. Steven Feld's seminal volume Sound and Sentiment (op. cit.) in many ways set the agenda for taking nonanthropocentric musicking seriously.

47. See cUSICK, "'You Are In a Place"'; an extended description of sounds as big relative to humans in combat zones can be found in DAUGHTRY J. Martin, "Thanatosonics: Ontologies of Acoustic Violence," Social Text, vol. 32, no. 2 (119), 2014, pp. 25-51.

48. The youtube video "Star Wars Minus Williams: Ewok Celebration" provides a decent illustration of the cumulative role music has played in naturalizing slow environmental violence. By replacing John Williams's lush musical soundtrack with the ambient sound of birds, woodland insects, fire, and explosions, the scene, which involves the incineration of Darth Vader's corpse and an ostentatious fireworks display, reveals layers of environmental fragility and entanglement that are impalpable in the original (https://www.youtube.com/watch? v=iG9WVDvVd0E, consulted on 27 February 2020).

49. As Ochoa Gautier writes, "recognizing potentialities is not the same as proposing an inherent ontology or political outcome in which such potentialities are prefigured as actualizations that only take one form: as a positivity of the political in music, sound, and listening" ("Acoustic Multinaturalism," p. 129).

50. See LEVINE and ROBINSON (eds.), Music and Modernity for a number of perspectives on this issue. Trevor Reed's essay in that volume states the case clearly: “...Indigenous ceremonial performances are originally owned by those who create and perform them and, if the creators or performers are no longer living, their lineal descendants or those who carry on the ceremonial practices. Indigenous peoples, therefore, have the right to control how recordings of their ceremonial culture circulate" (REED Trevor, "Pu-Itaaqatsit aw Tuuqayta (Listening to Our Modern Lives)", LEVINE and ROBINSON (eds.), Music and Modernity, p. 260).

51. On intersensoriality, vibrational practice, and materiality, see EIDSHEIM Nina, Sensing Sound; on relationality and "sound knowledge", see KAPCHAN Deborah, "The Splash of Icarus: Theorizing Sound Writing / Writing Sound Theory", KAPCHAN Deborah (ed.), Theorizing Sound Writing, Middletown (CT), Wesleyan University Press, 2017, pp.1-22; on respecting multiple musical ontologies, see SYKES Jim, “The Anthropocene and Music Studies”, Ethnomusicology Review, vol. 22, no. 1, 2019, pp. 4-21. Kyle Devine's 2019 monograph Decomposed: The Political Ecology of Music (Cambridge, MA, MIT Press, 2019) participates powerfully in this project by tracing the material 
roots of the music recording industry, from shellac to petrochemicals to the internet's many human and environmental entanglements.

52. For a meditation on "listening awry," see DROBNICK Jim, "Listening Awry", DROBNICK Jim (ed.), Aural Cultures, Toronto, YYZ Books, 2004, pp. 9-15.

53. SCHAFER R. Murray, Soundscape: Our Sonic Environment and the Tuning of the World, Rochester (VT), Destiny Books, 1994 [1977], p. 5.

54. Here I have in mind works by people such as John Luther Adams, David Dunn, Brother Nut, Andrea Polli, Juliana Snapper, Tanya Tagaq, Barry Truax, Hildegard Westerkamp, the Ear to Earth community, and especially Annea Lockwood, who composed the first set of instructions for burning (and sinking, and burying) pianos.

55. GHOSH Amitav, The Great Derangement: Climate Change and the Unthinkable, Chicago, University of Chicago Press, 2016, p. 11.

56. The final movement of earth's biospheric performance will be quite complex. For one chilling projection, see Ethan Siegel, "How Our Solar System Will End in the Far Future", Forbes, 27 January 2017 (https://www.forbes.com/sites/startswithabang/2017/01/27/how-our-solarsystem-will-end-in-the-far-future, consulted on 27 February 2020).

57. FitZGerald Ella with Tommy Flanagan, "Every Time We Say Goodbye" (https:// www.youtube.com/watch?v=gF5vjdrEuy4, consulted on 27 February 2020).

\section{ABSTRACTS}

This essay seeks to clarify the relationship between music and environmental violence. After a reflection on the distortions and insights that different frames of reference produce, it places music within an expansive environmental register that encompasses the entirety of human history, up to and including our current era of "slow violence," industrial pollution, mass extinction, and global warming. Throughout, human musicking is presented as always-already entangled with nonhuman entities and processes. The essay focuses on four of music's potentialities-its exclusivity, centripetality, instrumentality, and reductivity-and argues that the cumulative effect of musicking has been to help perpetuate a type of anthropocentrism that made industrial-scale environmental violence possible. It concludes by suggesting a number of small tactics for musical thriving in an age when, in Timothy Morton's words, "the concept of world is no longer operational".

Cet article propose de caractériser la relation entre musique et violence environnementale. Après une réflexion sur les perceptions et distorsions découlant des différents cadres de référence, il s'agit d'examiner la musique dans le registre environnemental le plus large, qui couvre la totalité de l'histoire humaine jusqu'à notre ère de "violence lente», de pollution industrielle, d'extinction de masse, et de réchauffement planétaire. Le musiquer humain doit alors être présenté dans son enchevêtrement systématique avec des entités et processus non-humains. L'article se concentre sur quatre potentialités de la musique - exclusive, centripète, instrumentale et réductive -, et défend qu'elle a eu pour effet cumulatif d'aider à la perpétuation d'une forme d'anthropocentrisme qui a rendu possible la violence environnementale à une échelle industrielle. Il se conclut sur quelques petites tactiques d'épanouissement musical à une époque où, à en croire Timothy Morton, « le concept de monde n'est plus opérationnel ». 


\section{INDEX}

Mots-clés: musique, violence, environnement, pollution, anthropocène, réchauffement planétaire, apocalypse, anthropocentrisme, trans-corporéité, fragilité, non-humain

Keywords: music, violence, environment, pollution, anthropocene, global warming, apocalypse, anthropocentrism, trans-corporeality, fragility, nonhuman

\section{AUTHOR}

\section{J. MARTIN DAUGHTRY}

J. Martin Daughtry is an associate professor of music and sound studies at New York University. He teaches and writes on acoustic violence; human and nonhuman vocality; listening; jazz; Russian-language sung poetry; sound studies; and the auditory imagination. His monograph, Listening to War: Sound, Music, Trauma, and Survival in Wartime Iraq (Oxford 2015) received a PROSE Award from the Association of American Publishers, and the Alan Merriam Prize from the Society for Ethnomusicology. He is currently writing a book on voice, atmosphere, and environmental fragility. 